囚Л. М. Слободченко, З. А. Шкіряк-Нижник, А. І. Мацола

ДУ «Інститут.педіатрї, акушерства та гінекологї̈НАН України»

\title{
ТИПИ ВІДНОСИН БАТЬКІВ І ПІДЛІТКІВ 15-18 РОКІВ У ПРОМИСЛОВОМУ МІСТІ (за результатами проекту «Сім'я та діти України»)
}

ТИПИ ВІДНОСИН БАТЬКІВ І ПІДЛІТКІВ 15-18 РОКІВ У ПРОМИСЛОВОМУ МІСТІ (ЗА РЕЗУЛЬТАТАМИ ПРОЕКТУ «СІМ'Я ТА ДІТИ УКРАЇНИ»), У рамках програми дослідження проведена діагностика батьківських відносин за тестом батьківського ставлення до підлітка, Всього опитано 1075 батьків, Встановлено гендерні відмінності типів батьківського ставлення: за шкалами «прийняття-відторгнення», «кооперація», «симбіоз», «авторитарна гіперсоціалізація/контроль», «ставлення до невдач дитини», Даний тест рекомендовано до застосування 3 метою як вивчення переважного стилю сімейного виховання, так і своєчасної діагностики, яка може допомогти провести відповідну корекційну роботу у відносинах між підлітком та батьками,

ТИПЫ ОТНОШЕНИЙ РОДИТЕЛЕЙ И ПОДРОСТКОВ 15-18 ЛЕТ В ПРОМЫШЛЕННОМ ГОРОДЕ (ПО РЕЗУЛЬТАТАМ ПРОЕКТА «СЕМЬЯ И ДЕТИ УКРАИНЫ»), В рамках программы исследования проведена диагностика родительских отношений по тесту родительского отношения к подростку, Всего опрошено 1075 родителей, Установлено гендерные различия типов родительского отношения: по шкалам «принятие-отторжение», «кооперация», «симбиоз», «авторитарная гиперсоциализация/контроль», «отношение к неудачам ребенка», Данный тест рекомендуется к применению с целью как изучения преимущественного стиля семейного воспитания, так и своевременной диагностики, которая может помочь провести соответствующую коррекционную работу в отношениях между подростком и родителями,

TYPES OF RELATIONSHIP OF PARENTS AND ADOLESCENTS 15-18 YEARS IN THE INDUSTRIAL CITY (BASED ON THE PROJECT «FAMILY AND CHILDREN OF UKRAINE»), In the frame of Family and children of Ukraine project 1075 parents were questioned on their attitude to relation with their teenagers, Gender difference of types of parental attitudes were established using the scales «acceptane-alienation», «cooperation», «symbiosis», "authoritorian hipersotialization/control», «attitude to child failure», This test is recommended for use in examind fion of predominant style of family upbringing as well for early diagnostics that can help to introduce corrections in parents-teens relations if needed,

Ключові слова: підлітки, батьки, тест батьківського ставлення,

Ключевые слова: подростки, родители, тест родительского отношения,

Key words: teenagers, parents, parental attitude,

ВСТУП. Першим стійким колективом ужитті кожної дитини є сім'я - перша сходинка соціалізації та самосвідомості особистості. Кожен з батьків вибирає власні стратегію і стиль виховання дитини, найбільш правильні на їх думку [1, 2].

У батьків, які надмірно захищають свою дитину, дитина найчастіше займає показну позицію. Вона зосереджує на собі увагу оточуючих. Потреби цих підлітків домінують над потребами інших членів сім'ї. До такого підлітка ставляться як до божества, якому всі служать. Подібну позицію частіше займає єдина в сім'ї дитина або наймолодша, або дитина, схильна до захворювань, про здоров'я якої батьки надмірно турбуються.

Коли батьки ухиляються від спілкування 3 підлітком, не беруть участі в його житті, постійно зайняті своїми справами - він почуває себе зайвим у сім'ї, в нього не формуються належні життєві позиції [3].

Підліток, від якого занадто багато вимагають, якого примушують і яким командують, теж не має міцної належної позиції. На ньому концентрується увага батьків, однак до нього висуваються вимоги, яких не ставлять перед іншими членами сім'ї, і це боляче сприймає підліток [4, 5].
Згадані типи відносин батьків з підлітками травмують їх психіку і порушують гармонійний психоемоційний стан, а відтак можуть негативно вплинути на стан фізичного здоров'я.

Правильні виховні позиції батьків полягають перш за все в сприйнятті підлітка як особистості, визначають одночасно і позицію підлітка в сім'ї як повноправного члена, до прав та потреб якого ставляться в рідному домі з повагою.

МАТЕРІАЛИ ТА МЕТОДИ. У рамках програми дослідження була проведена діагностика батьківських відносин за тестом батьківського ставлення до підлітка [6].

Батьківське ставлення тут розуміється як система різноманітних почуттів відносно підлітка, поведінкових стереотипів, що практикуються в спілкуванні 3 ним, особливостей виховання і розуміння характеру й особистості підлітка, його вчинків. Усього було опитано 1075 батьків, які мали підлітків 15-18 років.

Тест складався з 61 твердження, щодо яких батьки мали відповісти, згідні вони з ними чи ні. При обробці відповідей, які оцінювались у балах, дані розподілялись за п'ятьма шкалами, що відповідали різним типам батьківського ставлення: «прийняттявідторгнення», «кооперація», «симбіоз», «авторитар- 


\section{Педіатрія}

на гіперсоціалізація/контроль», «ставлення до невдач дитини».

РЕЗУЛЬТАТИ ДОСЛІДЖЕННЯ ТАЇХ ОБГОВОРЕННЯ. Високі значення за шкалою «прийняття-відторгнення» відображають емоційне ставлення до підлітка. Ставлення позитивне - прийняття, коли батькам підліток подобається таким, яким він є. Таке ставлення до підлітка мали, за даними дослідження, лише $0,2 \%$ батьків (серед хлопців - 0,2 \% батьків, серед дівчат - 0,2 \%). Ці батьки поважають його індивідуальність, симпатизують йому, прагнуть проводити багато часу з ним, схвалюють його інтереси і плани.

Низький показник за шкалою, навпаки, свідчить про відторгнення підлітка. Батьки сприймають його швидше поганим, непристосованим, невдахою. їм здається, що він не досягне успіху в житті через низькі здібності. Найчастіше батьки відчувають до такого підлітка злість, досаду, роздратування, образу. Вони не довіряють йому і нерідко своїм ставленням практично зневажають його.

За даними дослідження, таке ставлення мали 4,35\% батьків (серед хлопців - 4,4 \% батьків, серед дівчат - 4,3 \%), які продемонстрували значну психологічну дистанцію між собою і підлітком. Це достатньо висока частка «відторгнутих» дітей.

Шкала «кооперація» відображає ступінь соціально бажаного образу батьківського ставлення до підлітка: батьки зацікавлені у справах і планах підлітка, намагаються у всьому йому допомогти, співчувають йому; високо оцінюють його інтелектуальні та творчі здібності, відчувають гордість за нього, заохочують ініціативу і самостійність підлітка, намагаються бути з ним на рівних, довіряють йому. Такої моделі виховання дотримуються 79,5 \% батьків (серед хлопців - 79,0 \% батьків, серед дівчат - 80,1 \%).

Протилежна модель виховання в питаннях кооперації характерна для 0,4 \% батьків (серед хлопців - 0,6 \% батьків, серед дівчат - 0,2 \%).

Шкала «симбіоз» відображає міжособистісну дистанцію у спілкуванні з підлітком. Високі бали за цією шкалою свідчать про те, що батьки прагнуть до симбіотичних відносин з ним. Таке ставлення до підлітка $€$ характерним для 24,4 \% батьків (серед хлопців 21,2 \% батьків, серед дівчат - 27,6 \%). Батьки відчувають себе з ним єдиним цілим, прагнуть задовольнити всі його потреби, відгородити його від труднощів життя.

Шкала «авторитарна гіперсоціалізація/контроль» відображає форму і напрямок контролю за поведінкою підлітка. При високому балі за цією шкалою у батьків чітко проглядається авторитарна модель виховання. Такої моделі виховання дотримуються 20,85 \% батьків (серед хлопців - 20,8 \% батьків, серед дівчат - 20,9 \%). Батьки вимагають від дитини беззастережної покори і дисципліни, вони намагаються нав'язати в усьому свою волю, не готові стати на ії бік і підтримати ії точку зору. За прояви своєї волі підлітка карають.

Низькі бали за даною шкалою свідчать про те, що контроль за діями дитини з боку дорослої людини слабкий або практично відсутній. Це, безумовно, неправильний підхід до виховання підлітка. Така модель поведінки характерна для 9,9 \% батьків (серед хлопців - 10,9 \% батьків, серед дівчат - 8,8 \%).

Шкала «ставлення до невдач дитини» відображає особливості сприйняття і розуміння підлітка батьками. Високі бали за даною шкалою є ознакою того, що батьки вважають підлітка невдахою і ставляться до нього як до ще незрілої особи. Вони прагнуть зберегти дитячу психіку, приписати йому особисту і соціальну неспроможність. Батьки бачать підлітка молодшим порівняно з реальним віком. Інтереси, захоплення, думки і почуття підлітка здаються їм несерйозними, і вони ігнорують їх. Такий підліток не пристосований до реального життя, не успішний, відкритий для поганого впливу та вчинків. Такої думки про своїх дітей-підлітків дотримуються 0,55\% батьків (серед хлопців - 0,7 \% батьків, серед дівчат $-0,4 \%)$.

Низькі бали за даною шкалою свідчать про те, що невдачі підлітка батьки вважають випадковими і вірять у його майбутнє. Такі переконання характерні для 4,35 \% батьків (серед хлопців - 4,4 \% батьків, серед дівчат - 4,3\%).

Таким чином, у ході аналізу встановлено, що міжособистісні відносини в сім'ї з дітьми-підлітками є різними і мають певні гендерні відмінності.

ВИСНОВКИ. Відомо, що однією з головних причин формування передневротичних станів і невротичних розладів у підлітка є психотравмуючі переживання в міжособистісній сфері - сімейній. У сімейній сфері для підлітка важливі добрі стосунки в родині. Відсутність злагоди в родині або неадекватне ставлення батьків до виховання своїх дітей $€$ значними стресогенними чинниками, які можуть викликати психоемоційний зрив. Важливим психологічним аспектом профілактики психосоматичних порушень і загострень хронічних соматичних захворювань серед школярів підліткового віку є корекція відносин у сім'ї силами педіатрів і психологів на підставі роз'яснювальних бесід та відповідної психологічної корекції.

ПЕРСПЕКТИВИ ПОДАЛЬШИХ ДОСЛІДЖЕНЬ. ВИконане дослідження буде продовжено шляхом вивчення впливу типів виховання на розвиток і стан здоров'я підлітків, що в перспективі дасть можливість розробити методи та прийоми психокорекції відносин між батьками і підлітками. 


\section{Педіатрія}

\section{СПИСОК ЛІТЕРАТУРИ}

1. Авдеева Т. Г. Детско-родительские отношения как фактор развития познавательных способностей детей / Т. Г. Авдеева / Психология в России и за рубежом : материалы II Междунар. науч. конф. (Санкт-Петербург, ноябрь 2013 г.). - СПб. : Реноме, 2013. - 142 с.

2. Ефремова В. В. Соционический подход к воспитанию ребенка на примере дуальных и конфликтных отношений / В. В. Ефремова // Психология и соционика межличностных отношений. - 2010. № 7. - С. 20-24.

3. Пономарева И. В. Исследование психологических функций личностной беспомощности у подростков в семьях с различными стилями семейного воспитания / И. В. Пономарева // Фундаментальные исследования. - 2013. - № 4 (часть 1). - С. 138-144.
4. Евлашкина Н. М. Влияние различных стилей детско-родительских отношений на проявление агрессивного поведения у подростков с девиантным поведением / Н. М. Евлашкина // Неврологический вестник. Журнал им. В. М. Бехтерева. - 2011. - Т. 43, № 3. - С. 16-20.

5. Инина-Понуровская Е. Ю. Конфликтные отношения между родителями и детьми / E. Ю. ИнинаПонуровская // Актуальные вопросы современной психологии : материалы Междунар. науч. конф. (Челябинск, март 2011 г.). - Челябинск : Два комсомольца, 2011. - 142 с.

6. Практическая психодиагностика. Методики и тесты : учебное пособие. - Самара : Издательский Дом «Бахрах-М», 2002. - 672 с. 